\title{
Chapter 6 Vegetation Survey, Classification and Mapping in Angola
}

\author{
Rasmus Revermann and Manfred Finckh
}

\begin{abstract}
Spatial information about plant species composition and the distribution of vegetation types is an essential baseline for natural resource management planning. In Angola, the first countrywide vegetation map was elaborated by Gossweiler in 1939. Subsequently, Barbosa published a revised map with much higher detail in 1970 and his work has remained the main reference for the vegetation of Angola until today. However, these early maps were expert drawn and were not based on systematic surveys. Instead, the delimitation of vegetation units was based on many years of field observations and also incorporated results of local studies carried out by other authors. In spite the rich history of the scientific exploration of Angola's vegetation in colonial times, quantitative and plot based studies were rare. After the end of the armed conflict, new vegetation surveys making use of new methodological developments in numerical approaches to vegetation classification in combination with modern remote sensing imagery have provided spatial information of unprecedented detail. However, vast areas of the country still remain seriously understudied. At the same time, sustainable land management strategies are urgently needed due to the increasing pressure on natural resources driven by socio-economic development and global change, thus calling for a new era of vegetation surveys that will enable data-based landuse and conservation planning in Angola.
\end{abstract}

Keywords Conservation - Landuse planning - Natural resources · Plant communities $\cdot$ Remote sensing

R. Revermann $(\bowtie) \cdot$ M. Finckh

Institute for Plant Science and Microbiology, University of Hamburg, Hamburg, Germany

e-mail: rasmus.revermann@gmail.com; manfred.finckh@uni-hamburg.de 


\section{Introduction}

Knowledge on the spatial distribution of vegetation and its species composition is paramount for any kind of natural resource management and conservation planning. Vegetation serves as habitat for other organismic groups and is the source of energy in the ecosystem. As such, vegetation integrates many ecological processes and reflects patterns of topography, geology, soil, hydrology and climate. Thus, vegetation classification is ideal to provide an aggregated image of the landscape and its ecological communities.

\section{Historical Exploration of Vegetation Patterns in Angola}

First reports on the vegetation of Angola were directly linked to the floristic exploration of the country, as outlined by Goyder and Gonçalves (2019). Scientific missions during colonial times in Angola served several purposes: on the one hand they should chart the potential for economic exploitation and development while on the other hand they may also have been used to demonstrate the supremacy of the colonial power (Gago et al. 2016). The expedition by the geographer Jessen (1936) provided a first sketch of the vegetation along the routes of his transects through western Angola. Jessen's work remains a classic as he was among the first to document the landscape and ecosystem properties of the region. However, it is hardly read today as it is only available in German.

The systematic descriptions of the vegetation of Angola started with Gossweiler and Mendonça's (1939) phytogeographical map of Angola. The often-cited English summary by Shaw (1947) contributed much to the recognition of Gossweiler's work internationally. The map is based on the combined structural and ecological approach to vegetation classification developed by Brockmann-Jerosch and Rübel (1912) in Zurich. Thus, in a first level of classification they categorised the vegetation according to woodiness and persistence into the three categories Lignosa (woody), Herbosa (herbaceous) and Deserta (land surfaces without permanent vegetation cover). The next step of the classification included climatic and edaphic factors, as well as leaf traits, leading for instance to five sub-categories of woody vegetation called Pluviilignosa, Laurilignosa, Durilignosa, Ericilignosa, Aestililignosa and Hiemilignosa. Stand structure was the main criterion for the next categories, dividing the afore-mentioned categories between tall forests (-silva) and dense but low forests (-fruticeta) (e.g. Pluviisilva vs. Pluviifruticeta or Durisilva vs. Durifruticeta). Below this third level we finally find floristically defined vegetation units, albeit mostly named after one or two dominant species. Similar structural criteria were used for the sub-classification of the Herbosa and Deserta.

The vegetation map used this rather rigid classification scheme for the 19 main mapping units. However, the resulting map apparently did not fully satisfy the authors, who then applied 29 additional symbols to indicate occurrence of small- 
scale vegetation units, of transition zones and of species that appeared to be of special interest to the authors - a very nice real world example of dealing with rigid mapping manuals. However, neglecting these small methodological inconsistencies, the map by Gossweiler \& Mendonça presented the first overall picture of the vegetation of Angola, a first approach towards a systematic compilation of observations of phytogeographical patterns and a first attempt at ecological interpretation. While many of the mapped polygons seem outdated in times of modern earth observation, the number of observed details in remote parts of Angola is still surprising for today's botanists. The authors were probably the first to report for Angola on invasive species, on seed dispersal by bats, on the morphological plasticity of the genus Syzygium and on many other current scientific topics. Also quite astonishing was the classification of the suffrutex grassland within the woody vegetation types (Ericifruticeta), more than 30 years before White (1976) published the groundbreaking paper on the 'Underground forests of Africa'.

The next important integrating step towards a synthesis on the vegetation units of Angola and their spatial distribution was Grandvaux Barbosa's phytogeographical map of Angola (Barbosa 1970). His work can be seen as a continuation and extension of the Gossweiler approach. The map clearly benefited from several regional studies that had been carried out in the meantime (see below) and of course also from Barbosa's own knowledge gained during several field missions throughout the country and his extensive experience of similar vegetation types found in Mozambique. As ancillary information Barbosa included descriptions of the main soil types and climatic zones of Angola.

The mapping approach adopted by Barbosa was to some degree harmonised with the parallel efforts of the Flora Zambesiaca map and the UNESCO initiative mapping the vegetation of Africa. The first level of classification differentiates the vegetation based on the formation, i.e. deals with the physiognomy of the vegetation such as closed forests, forest savanna mosaics, woodlands etc. and beyond that includes azonal edaphic vegetation units such as mangrove stands and coastal dune vegetation. In the second level of classification vegetation types are distinguished according to dominant species. In total, the map by Barbosa displays 32 main vegetation types and the descriptive text accompanying the map provides details on over 100 subordinate types (for a brief summary in English see Barbosa 1971).

The result was a good overview of the main vegetation types of Angola, in terms of spatial patterns much superior to the first attempt by Gossweiler and Mendonça (1939). Until today the vegetation units of the map by Barbosa (1970) constitute the foundation for the Angolan part of most continental or global scale vegetation maps (see below). However, due to Barbosa's floristic rather than ecological emphasis, the report on the vegetation units did neither contribute much to a better understanding of the ecology of the main vegetation patterns, nor did it make use of a modern classification concept based on plant communities.

Shortly after Barbosa's vegetation map, Diniz (1973) published a monograph on the physical properties of the agricultural zones of Angola. Included in this monograph, are soil and vegetation maps for 36 agricultural zones, albeit in rather fragmented components and without an overall map of the country. The vegetation 
classification scheme he used is not clearly defined, somewhere in between those of Gossweiler and Barbosa, but sometimes with more detail than Barbosa (1970). The main achievement of Diniz (1973) is that he assembled sound environmental information (with a focus on geology and soils) for all delimited agricultural zones. However, due to the lack of a seamless map and his unclear classification approach his contribution to the knowledge on the vegetation of Angola did not receive much attention in the subsequent scientific literature and due to the violent conflicts following Angola's independence in 1975, Barbosa's work has remained the main reference on the vegetation of Angola.

\section{Integration of the Vegetation Map of Angola Within Continental Scale Maps}

The next important step for a better understanding of Angolan vegetation was the UNESCO/AETFAT/UNSO initiative for a Vegetation Map of Africa (UNESCO/ AETFAT/UNSO 1981), compiled and described by White (1983). For Angola the continental map is largely based on the units supplied by Barbosa (1970) but they were subject to further generalisation resulting in only 14 mapping units compared to Barbosa's 32 vegetation types. However, the important achievement of White's map lies in the fact that it inserted Angolan vegetation in a common conceptual and methodological framework with the vegetation of neighbouring countries and the African continent as a whole. As such, the UNESCO (UNESCO/AETFAT/UNSO 1981)/(UNESCO 1981) map and White's (1983) description established the now widely used term 'miombo woodlands' in our scientific and geographic frameworks, allowing thus for the comparison of Angola's ecosystems with similar vegetation types throughout Africa. Although Barbosa and White provided seamless maps covering the entire country, the level of information supporting the mapping units varies strongly and for some units, especially in the more remote eastern parts of the country, barely any details are given. All these early maps are based on expert knowledge and no quantitative data was involved in the process of map making.

The Vegetation Map of Africa then again was the main baseline for the WWF's approximation of the world's terrestrial ecoregions (Olson et al. 2001) in so far as the African continent was concerned. Although without a presentation of a systematic biogeographical database, the map of the terrestrial ecoregions currently constitutes the most used baseline map for strategic conservation planning on a continental and subcontinental scale (e.g. MacKinnon et al. 2016). The availability of modern remote sensing techniques has allowed the generation of continental or global land cover products, i.e. GlobCover, MODIS/Terra Land Cover, GlobLand30 or the map of African ecosystems by Sayre et al. (2013). However, these maps display structural vegetation types only and provide no floristic information. 


\section{Regional and Local Studies on Vegetation Composition}

Early plot based studies were conducted by Ilse von Nolde on the Planalto de Quela (von Nolde 1938a, b, c). Since the mid-1950s, several local studies based on missions assessing natural resources were carried out at the regional level in Angola. Monteiro studied the forest resources in Moxico (Monteiro 1957), in the northern Maiombe and Dembos forests (Monteiro 1962, 1965a, b, 1967), and in Bié (Monteiro 1970a) contributing to our knowledge on species composition in the respective forest types. Monteiro's (1970a, b) work in Bié needs to be highlighted as for Angola he implemented new methods in mapping the vegetation. His map of the woody vegetation of the province of Bié is not drawn based on pure observations but is based on quantitative vegetation plot data. He collected data on species composition in 144 vegetation relevés sized $30 \mathrm{~m} \times 30 \mathrm{~m}$ that were subject to a vegetation classification based on vegetation tables. The mapping process was guided by aerial photography, quite an advanced approach for its time. Menezes $(1965,1971)$ undertook phytosociological studies and produced local vegetation maps in pastoral ecosystems of the Cunene Province. Teixeira elaborated vegetation maps for two of the main protected areas of Angola, the Quiçama and Bicuar national parks (Teixeira et al. 1967; Teixeira 1968). A few years later, Huntley produced a much more detailed map of the Quiçama National Park in 1972 at a scale of 1:100000 depicting 28 plant communities (Huntley 1972). Aguiar and Diniz (1972) mapped the vegetation of the western plateau of Cela. Coelho explored the potential of forestry in Cuando Cubango and elaborated a classification of the lower Cubango Basin into 32 forestry zones (Coelho 1964, 1967). Santos (1982) used a transect approach, so called 'itinerários florísticos', in order to generate an expert-drawn vegetation map for Cuando Cubango Province (Fig. 6.1).

\section{Modern Approaches to Vegetation Mapping and Classification}

This early period of vegetation mapping and classification was followed by the absence of any such activities for the coming decades due to the long-lasting armed conflict in the country. During this period significant methodological advances were made in vegetation ecology and phytosociology as well as in remote sensing techniques. The advent of computers allowed the development of new methodological tools to semi-automatically classify large amounts of multivariate vegetation plot data based on objective criteria. As such, vegetation classification moved away from the subjective assignments of vegetation types to more formalised data analysis. Similarly, remote sensing imagery became readily available often at no cost and in unprecedented temporal and spatial resolution. Thus, new numerical methods together with modern remote sensing products have the potential to provide a much more detailed and objective picture of vegetation and plant diversity patterns than expert drawn maps and arbitrarily assigned vegetation types of earlier times (Fig. 6.2). 

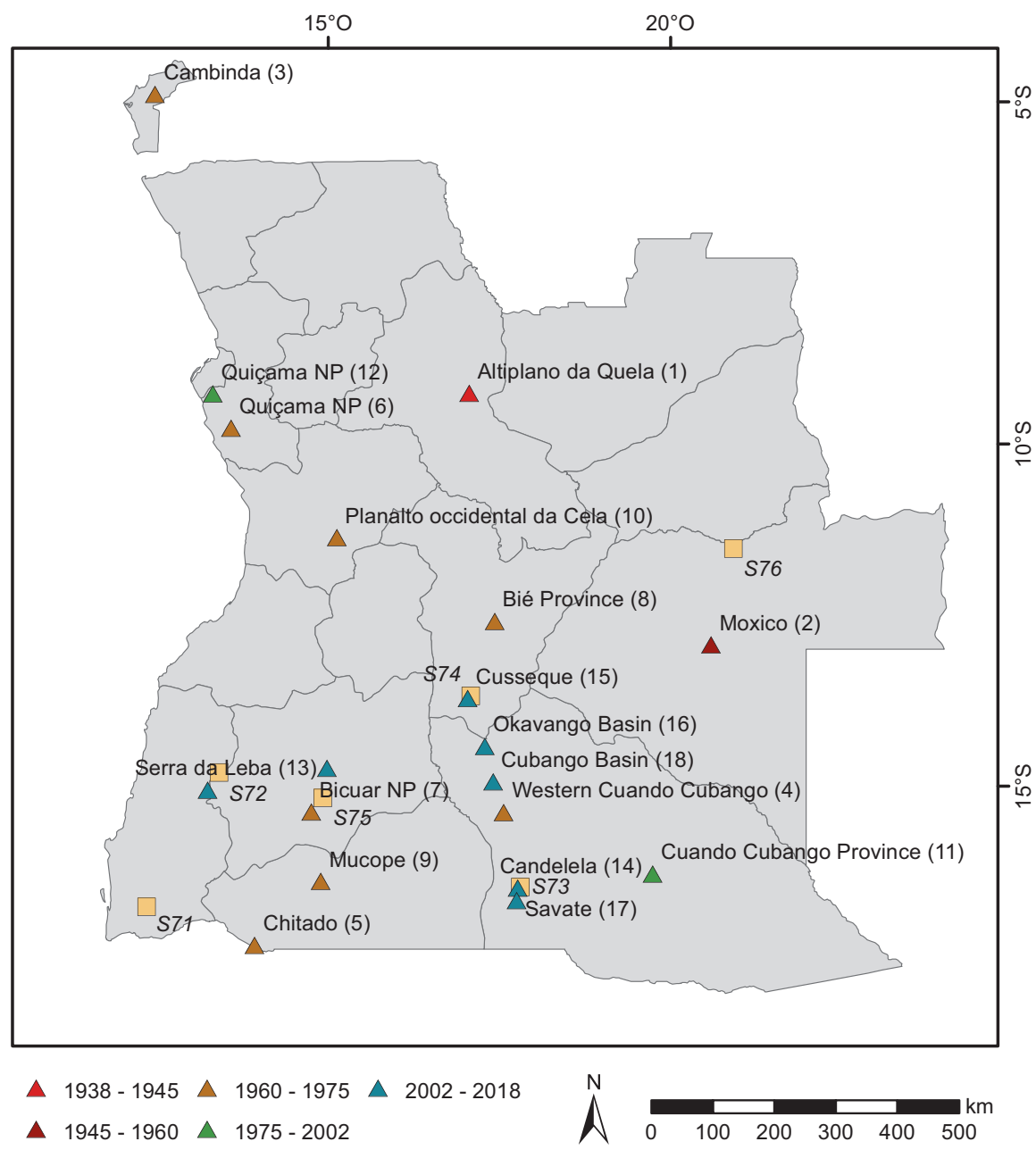

Biodiversity Observatories

Fig. 6.1 Location of regional and local studies on vegetation composition, vegetation classification or vegetation mapping approaches according to the year the study was published. The countrywide maps by Gossweiler and Mendonça (1939), Barbosa (1970) and Diniz (1973) are not depicted. (1) von Nolde 1938a, b, c (2) Monteiro 1957 (3) Monteiro 1962 (4) Coelho 1964 (5) Menezes 1965 (6) Teixeira et al. 1967, Huntley 1972 unpublished (7) Teixeira 1968 (8) Monteiro 1970a (9) Menezes 1971 (10) Diniz and Aguiar (1968) (11) dos Santos 1982 (12) De Bruyn and Eberle 2001 (13) Cardoso et al. 2006 (14) Revermann and Finckh 2013a (15) Revermann et al. 2013, Schneibel et al. 2013, Gonçalves et al. 2017 (16) Revermann and Finckh 2013b, Stellmes et al. 2013 (17) Wallenfang et al. 2015 (18) Revermann 2016, Revermann et al. 2018a (19) Chisingui et al. 2018. Furthermore, the six biodiversity observatories installed by the SASSCAL project are shown: Espinheira (S71), Tundavala (S72), Candelela (S73), Cusseque (S74), Bicuar National Park (S75), Cameia National Park (S76) 

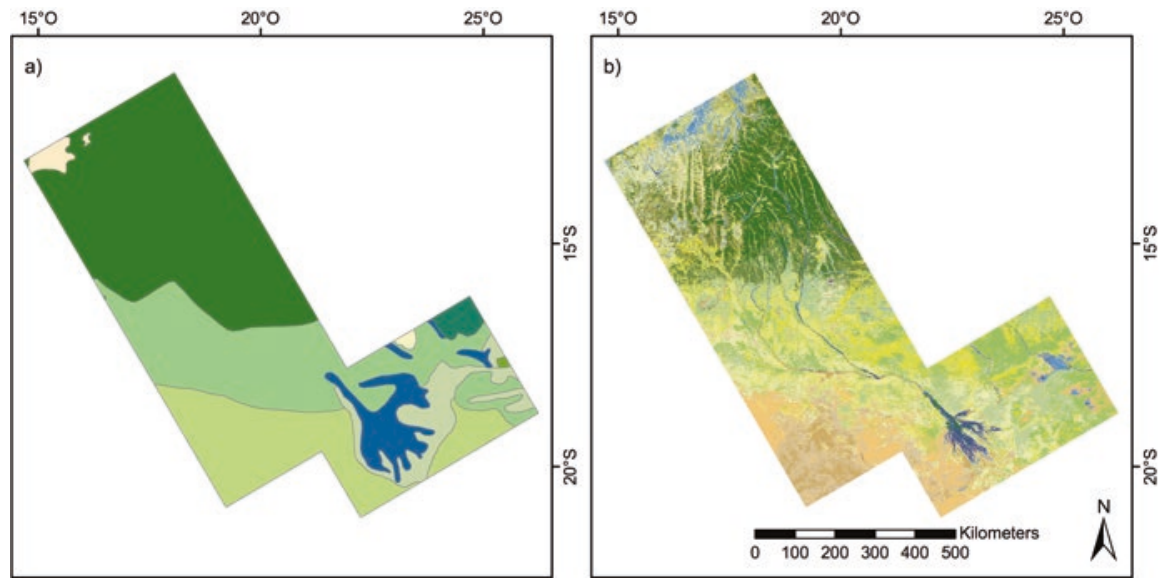

Fig. 6.2 Maps for the Okavango Basin located in southeast Angola and extending into Namibia and northern Botswana. (a) shows the ecoregions as defined by Olson et al (2001) which are largely based on the vegetation maps of Barbosa (1970) and White (1983), (b) Vegetation map produced for the same area by The Future Okavango project based on unsupervised classification of land surface phenology metrics derived from 16-day MODIS EVI time series from the years 2000-2011 (Stellmes et al. 2013) and interpreted using the information of vegetation plots stored in the vegetation database of the Okavango Basin (Revermann and Finckh 2013b; Revermann et al. 2016a). For an explanation of the vegetation units depicted in the maps please refer to the original publications

Recent years have seen increasing activity in the investigation of vegetation patterns at the local and regional scale. During the years 1995-2002 some vegetation surveys were carried out in the Quiçama National Park south of Luanda, for which the map elaborated by Huntley in the year 1972 served as a baseline. The activities aimed at gathering data for the re-establishment of the national park and to develop management strategies (Jeffery et al. 1996). De Bruyn and Eberle (2001) studied a small fenced of area in the north of the park where they collected 74 relevés and identified four plant communities including eight subcommunities. Additional quantitative data was collected to investigate grazing and browsing capacities. Cardoso et al. (2006) studied the vegetation communities along the steep altitudinal gradient of the Serra da Leba near Lubango.

Within The Future Okavango (TFO, www.future-okavango.org) project detailed investigations have been carried out in the Okavango (Cubango) River Basin. The project team assembled a vegetation database containing vegetation relevé data on all terrestrial vegetation types within the Okavango Basin (Revermann et al. 2016a). The plot design followed the standards implemented for woodland vegetation in the southern neighbour countries, i.e. a nested plot design of one small $10 \mathrm{~m} \times 10 \mathrm{~m}$ plot in a large $20 \mathrm{~m} \times 50 \mathrm{~m}$ plot (Strohbach 2001; Jürgens et al. 2012). Based on this data, classifications for local study sites based on numerical classification approaches have been published (Revermann and Finckh 2013a; Wallenfang et al. 2015) and a first classification of the terrestrial vegetation of the entire Cubango Basin was elaborated (Revermann et al. 2018a). 
The vegetation database of the Okavango Basin was also the foundation to produce a first vegetation map based on quantitative ground data for the Okavango Basin (Fig. 6.2b Revermann and Finckh 2013b; Stellmes et al. 2013) and allowed modelling the $\alpha$-diversity of vascular plants for the same region (Revermann et al. 2016b).

Based on vegetation relevés various studies have investigated the impact of land use on vegetation (Revermann et al. 2017) and studied the regeneration of the vegetation after land use had ceased (Wallenfang et al. 2015; Gonçalves et al. 2017, 2018).

Presently a number of vegetation classification and mapping initiatives are underway in the framework of the research project SASSCAL (Southern African Science Service Centre for Climate Change and Adaptive Land Management). For a compilation of project outcomes see Revermann et al. 2018b, e.g. in the Huíla Province (Chisingui et al. 2018) and along the coastal plain from the Cunene River to Benguela including Iona National Park (Jürgens et al. in prep.). The same project includes six newly implemented biodiversity observatories (http://www.sasscalobservationnet.org/), depicted on Fig. 6.1. The standardised monitoring of the $1 \mathrm{~km}^{2}$ sites (Jürgens et al. 2012) will allow the long term monitoring of changes in plant species composition and plant diversity. Zigelski et al. (2018) present first analyses of the data gathered on such a biodiversity observatory in the Cameia National Park.

\section{Outlook: A Call for a New Vegetation Survey of Angola}

Vegetation and natural resources in general are under strong pressure from the increasing demands of a growing population and the transition from traditional lifestyles to modern consumerism (cf. Pröpper et al. 2015). The main drivers of deforestation and degradation of woodlands and the general loss of pristine vegetation cover in Angola are the clearing of new fields for shifting cultivation, industrialised agricultural schemes and the production of charcoal (Cabral et al. 2010; Hansen et al. 2013; Schneibel et al. 2013, 2016, 2018; Röder et al. 2015; Wallenfang et al. 2015; Mendelsohn 2019). Without adequate knowledge of the spatial distribution and extent of vegetation types, their species composition and the environmental drivers of vegetation patterns (climate, geology, soils, landuse) sound landuse management is not feasible. Thus, a nationwide vegetation survey based on quantitative, plot level data is urgently needed. Combined with remote sensing data and ecological modelling tools an accurate vegetation map can be produced serving the needs of conservationists, planners, entrepreneurs and scientists alike. A successful vegetation survey however relies on good taxonomic knowledge, current flora compendia and plant identification guides. Functioning and strengthened herbaria are also of great importance building the capacity of the future generation of field ecologists and environmental scientists. 


\section{References}

Aguiar FQB, Diniz AC (1972) Carta de Vegetação do Planalto Ocidental da Cela: Estudo Interpretativo. Série Científica $\mathrm{N}^{\circ}$ 26. Instituto de Investigação Agronómica de Angola, Nova Lisboa

Barbosa LAG (1970) Carta Fitogeográfica de Angola. Instituto de Investigação Científica de Angola, Luanda, $323 \mathrm{pp}$

Barbosa LAG (1971) Phytogeographical map of Angola. Mitteilungen der Botanischen Staatssammlung München 10:114-115

Brockmann-Jerosch H, Rübel E (1912) Die Einteilung der Pflanzengesellschaften nach okologischphysiognomischen Gesichtspunkten. Engelmann, Leipzig, 72 pp

Cabral AIR, Vasconcelos MJ, Oom D et al (2010) Spatial dynamics and quantification of deforestation in the central-plateau woodlands of Angola (1990-2009). Appl Geogr 31(3):1185-1193

Cardoso J, Duarte M, Costa E et al (2006) Communidades vegetais da Serra da Leba. In: Moreira I (ed) Angola: Agricultura, Recursos Naturais e Desenvolvimento. ISA Press, Lisbon, pp 205-223

Chisingui AV, Gonçalves FMP, Tchamba JJ et al (2018) Vegetation survey of the woodlands of Huíla province. In: Revermann R, Krewenka KM, Schmiedel U et al (eds) Climate change and adaptive land management in southern Africa - assessments, changes, challenges, and solutions, Biodivers \& Ecol, vol 6. Klaus Hess Publishers, Göttingen \& Windhoek, pp 426-437

Coelho H (1964) Contribuição para o Conhecimento da Composição Florística e Possibilidades de uma Zona Compreendida entre os rios Cubango, Cueio e Quatir. Agronomia Angolana 20:49-82

Coelho H (1967) Zonagem Florestal do Distrito do Cuando-Cubango. Primeiros elementos. Agronomia Angolana 26:3-28

De Bruyn PJN, Eberle D (2001) An ecological study of the plant communities of the fenced sector of the Quiçama National Park, Angola, with Management Recommendations. B.Sc. (Hons) Thesis. University of Pretoria, Pretoria

Diniz AC (1973) Características mesológicas de Angola. Missão de Inquéritos Agrícolas de Angola, Nova Lisboa, $482 \mathrm{pp}$

Diniz AC, Aguiar FB (1968) Regiões Naturais de Angola. Série Científica No 2. Instituto de Investigação Agronómica de Angola, Nova Lisboa, 6 pp + 1 map

Gago MM, Macedo M, Castelo C (2016) Surveying Angola, São Tomé and Timor: experts and transnational practices. In: Serrão JV, Freire D, Fernández L (eds) Old and new worlds: the global challenges of rural history, Conference eBook. ISCTE - Instituto Universitário de Lisboa. Centro de Investigação e Estudos de Sociologia, Lisboa

Gonçalves FMP, Revermann R, Gomes AL, et al. (2017) Tree species diversity and composition of Miombo woodlands in south-central Angola, a chronosequence of forest recovery after shifting cultivation. Int J For Res 2017(6202093), 13 pp.

Gonçalves FMP, Revermann R, Cachissapa MJ, et al (2018) Species diversity, population structure and regeneration of woody species in fallows and mature stands of tropical woodlands of SE Angola. J For Res. Published online 13 January 2018

Gossweiler J, Mendonça FA (1939) Carta Fitogeográfica de Angola. Ministério das Colónias, Lisbon, $242 \mathrm{pp}$

Goyder DJ, Gonçalves FMP (2019) The flora of Angola: collectors, richness and endemism. In: Huntley BJ, Russo V, Lages F, Ferrand N (eds) Biodiversity of Angola. Science \& conservation: a modern synthesis. Springer Nature, Cham

Hansen MC, Potapov PV, Moore R et al (2013) High-resolution global maps of 21st-century forest cover change. Science 342(6160):850-853

Huntley BJ (1972) Parque Nacional da Quiçama. Carta da Vegetação, $1^{\circ}$ Aproximação Julho 1972. Ecologist's report 22. Repartição Técnica da Fauna, Serviços de Veterinária, Luanda, Mimeograph report

Jeffery RF, van der Waal C, Radloff F (1996) An ecological evaluation with management guidelines for the re-establishment of the Quiçama National Park, Angola. B.Sc. (Hons) thesis. University of Pretoria, Pretoria 
Jessen O (1936) Reisen und Forschungen in Angola. Dietrich Reimer Verlag, Berlin, 397 pp

Jürgens N, Schmiedel U, Haarmeyer DH et al (2012) The BIOTA biodiversity observatories in Africa-a standardized framework for large-scale environmental monitoring. Environ Monit Assess 184(2):655-678

MacKinnon J, Aveling C, Olivier R et al (2016) Inputs for an EU strategic approach to wildlife conservation in Africa - regional analysis. European Commission, Directorate-General for International Cooperation And Development, Brussels, 494 pp

Mendelsohn JM (2019) Landscape changes in Angola. In: Huntley BJ, Russo V, Lages F, Ferrand N (eds) Biodiversity of Angola. Science \& conservation: a modern synthesis. Springer Nature, Cham

Menezes JA (1965) Estudo fitosociológico e características das pastagens da região do Chitado. Boletim do Instituto de Investigação Científica de Angola 2(2):137-181

Menezes JA (1971) Estudo fitoecológico da região de Mucope e carta da vegetação. Boletim Instituto de Investigação Científica de Angola 8(2):7-54

Monteiro RFR (1957) Aspectos da exploração florestal no distrito do Moxico. Garcia de Orta 5(1):129-146

Monteiro RFR (1962) Le massif forestier du Mayombe angolais. Revue Bois et Forêts des Tropiques 82:3-17

Monteiro RFR (1965a) A formação florestal dos Dembos. Boletim do Instituto de Investigação Científica de Angola 2(1):71-82

Monteiro RFR (1965b) Correlação entre as florestas do Maiombe e dos Dembos. Indicação de factores predominantes. Boletim do Instituto de Investigação Científica de Angola 1(2):257-265

Monteiro RFR (1967) Essências Florestais de Angola. Estudo das Suas Madeiras. Espécies do Maiombe. Instituto de Investigação Científica de Angola, Luanda

Monteiro RFR (1970a) Estudo da Flora e da Vegetação das Florestas Abertas do Plantalto do Bié. Instituto de Investigação Científica de Angola, Luanda, 352 pp

Monteiro RFR (1970b) Alguns Elementos de Interese Ecológico da Flora Lenhosa do Planalto do Bié (Angola). Instituto de Investigação Científica de Angola, Luanda, 166 pp

Olson DM, Dinerstein E, Wikramanayake ED et al (2001) Terrestrial ecoregions of the world: a new map of life on earth. Bioscience 51(11):933-938

Pröpper M, Gröngröft A, Finckh M et al (2015) The future Okavango - findings, scenarios and recommendations for action. Research project final synthesis report 2010-2015. Hamburg, 190 pp

Revermann R (2016) Analysis of vegetation and plant diversity patterns in the Okavango basin at different spatial scales - integration of field based methods, remote sensing information and ecological modelling. PhD thesis, University of Hamburg Hamburg, $295 \mathrm{pp}$

Revermann R, Finckh M (2013a) Caiundo - vegetation. Biodivers Ecol 5:91-96

Revermann R, Finckh M (2013b) Okavango basin - vegetation. Biodivers Ecol 5:29-35

Revermann R, Gomes A, Gonçalves FM et al (2013) Cusseque - vegetation. Biodivers Ecol 5:59-63

Revermann R, Gomes AL, Gonçalves FM et al (2016a) Vegetation database of the Okavango basin. Phytocoenologia 46(1):103-104

Revermann R, Finckh M, Stellmes M et al (2016b) Linking land surface phenology and vegetationplot databases to model terrestrial plant alpha diversity of the Okavango Basin. Remote Sens 8:370

Revermann R, Wallenfang J, Oldeland J et al (2017) Species richness and evenness respond to diverging land-use patterns - a cross-border study of dry tropical woodlands in southern Africa. Afr J Ecol 55:152-161

Revermann R, Oldeland J, Gonçalvess FM et al (2018a) Dry tropical forests and woodlands of the Cubango Basin in southern Africa - first classification and assessment of their woody species diversity. Phytocoenologia 48(1):23-50

Revermann R, Krewenka KM, Schmiedel U et al (eds) (2018b) Climate change and adaptive land management in southern Africa - assessments, changes, challenges, and solutions. Biodivers Ecol 6:1-497

Röder A, Pröpper M, Stellmes M et al (2015) Assessing urban growth and rural land use transformations in a cross-border situation in northern Namibia and southern Angola. Land Use Policy 42:340-354 
Santos RM (1982) Itinerários Florísticos e Carta da Vegetacão do Cuando Cubango. Instituto de Investigação Científica Tropical, Lisbon, 265 pp

Sayre R, Comer P, Hak J et al (2013) A new map of standardized terrestrial ecosystems of Africa. Association of American Geographers, Washington, DC, $24 \mathrm{pp}$

Schneibel A, Stellmes M, Revermann R et al (2013) Agricultural expansion during the post-civil war period in southern Angola based on bi-temporal Landsat data. Biodivers Ecol 5:311-320

Schneibel A, Stellmes M, Röder A et al (2016) Evaluating the trade-off between food and timber resulting from the conversion of Miombo forests to agricultural land in Angola using multitemporal Landsat data. Sci Total Environ 548-549:390-401

Schneibel A, Röder A, Stellmes M et al (2018) Long-term land use change analysis in southcentral Angola. Assessing the trade-off between major ecosystem services with remote sensing data. Biodivers Ecol 6:360-367

Shaw HKA (1947) The vegetation of Angola. J Ecol 35(1):23-48

Stellmes M, Frantz D, Finckh M et al (2013) Okavango basin - earth observation. Biodivers Ecol 5:23-27

Strohbach BJ (2001) Vegetation survey of Namibia. J Namibia Sci Soc 49:93-124

Teixeira JB (1968) Parque Nacional do Bicuar. Carta da vegetação (1ª aproximação) e Memória Descritiva. Instituto de Investigação Agronómica de Angola, Nova Lisboa

Teixeira JB, Matos GC, Sousa JNB (1967) Parque Nacional da Quiçama. Carta da Vegetação e Memória Descritiva. Instituto de Investigação Agronómica de Angola, Nova Lisboa

UNESCO/AETFAT/UNSO (1981) Vegetation map of Africa - scale 1:5 000 000. In: White F (ed) UNESCO, Paris

von Nolde I (1938a) Probeflächen verschiedener Savannenformationen im Hochland von Quela in Angola. Notizblatt des Botanischen Gartens und Museums zu Berlin-Dahlem 14:298-311

von Nolde I (1938b) Probeflächen verschiedener Waldformationen aus dem Hochland von Quela in Angola. Notizblatt des Botanischen Gartens und Museums zu Berlin-Dahlem 14:483-486

von Nolde I (1938c) Botanische Studie über das Hochland von Quela in Angola. Feddes Repertorium Beihefte 101:35

Wallenfang J, Finckh M, Oldeland J et al (2015) Impact of shifting cultivation on dense tropical woodlands in southeast Angola. Trop Conserva Sci 8(4):863-892

White F (1976) The underground forests of Africa: a preliminary review. Gard Bull Singapore 11:57-71

White F (1983) The vegetation of Africa - a descriptive memoir to accompany the Unesco/ AETFAT/UNSO vegetation map of Africa. UNESCO, Paris, $356 \mathrm{pp}$

Zigelski P, Lages F, Finckh M (2018) Seasonal changes of biodiversity patterns and habitat conditions in a flooded savanna - the Cameia national park biodiversity observatory in the upper Zambezi catchment, Angola. In: Revermann R, Krewenka KM, Schmiedel U et al (eds) Climate change and adaptive land management in southern Africa - assessments, changes, challenges, and solutions, Biodivers Ecol, vol 6. Klaus Hess Publishers, Göttingen \& Windhoek, pp $438-447$

Open Access This chapter is licensed under the terms of the Creative Commons Attribution 4.0 International License (http://creativecommons.org/licenses/by/4.0/), which permits use, sharing, adaptation, distribution and reproduction in any medium or format, as long as you give appropriate credit to the original author(s) and the source, provide a link to the Creative Commons licence and indicate if changes were made.

The images or other third party material in this chapter are included in the chapter's Creative Commons licence, unless indicated otherwise in a credit line to the material. If material is not included in the chapter's Creative Commons licence and your intended use is not permitted by statutory regulation or exceeds the permitted use, you will need to obtain permission directly from the copyright holder. 